\title{
SLC51 family of steroid-derived molecule transporters (version 2020.4) in the IUPHAR/BPS Guide to Pharmacology Database
}

\author{
Paul A. Dawson ${ }^{1}$ \\ 1. Emory University, USA
}

\begin{abstract}
The SLC51 organic solute transporter family of transporters is a pair of heterodimeric proteins which regulate bile salt movements in the small intestine, bile duct, and liver, as part of the enterohepatic circulation [2, 4, 1]. OST $\alpha /$ OST $\beta$ is also expressed in steroidogenic cells of the brain and adrenal gland, where it may contribute to steroid movement [5]. Bile acid transport is suggested to be facilitative and independent of sodium, potassium, chloride ions or protons $[4,2]$. OST $\alpha /$ OST $\beta$ heterodimers have been shown to transport $\left[{ }^{3} \mathrm{H}\right]$ taurocholic acid, $\left[{ }^{3} \mathrm{H}\right]$ dehydroepiandrosterone sulphate, $\left[{ }^{3} \mathrm{H}\right]$ estrone-3-sulphate, $\left[{ }^{3} \mathrm{H}\right]$ pregnenolone sulphate and $\left[{ }^{3} \mathrm{H}\right]$ dehydroepiandrosterone sulphate $[2,4,5]$. OSTa/OST $\beta$-mediated transport of bile salts is inhibited by clofazimine [9]. OSTa is suggested to be a seven TM protein, while OST $\beta$ is a single TM 'ancillary' protein, both of which are thought to have intracellular C-termini [7]. Both proteins function in solute transport [7, 3]. Inherited mutations in OST $\alpha$ and OST $\beta$ are associated liver disease and congenital diarrhea in children $[8,6]$.
\end{abstract}

\section{Contents}

This is a citation summary for SLC51 family of steroid-derived molecule transporters in the Guide to Pharmacology database (GtoPdb). It exists purely as an adjunct to the database to facilitate the recognition of citations to and from the database by citation analyzers. Readers will almost certainly want to visit the relevant sections of the database which are given here under database links.

GtoPdb is an expert-driven guide to pharmacological targets and the substances that act on them. GtoPdb is a reference work which is most usefully represented as an on-line database. As in any publication this work should be appropriately cited, and the papers it cites should also be recognized. This document provides a citation for the relevant parts of the database, and also provides a reference list for the research cited by those parts.

Please note that the database version for the citations given in GtoPdb are to the most recent preceding version in which the family or its subfamilies and targets were substantially changed. The links below are to the current version. If you need to consult the cited version, rather than the most recent version, please contact the GtoPdb curators.

\section{Database links}

SLC51 family of steroid-derived molecule transporters

http://www.guidetopharmacology.org/GRAC/FamilyDisplayForward?familyld=337

Transporters

OSTa(Organic solute transporter subunit $\alpha)$

http://www.guidetopharmacology.org/GRAC/ObjectDisplayForward?objectld=1915

OST $\beta$ (Organic solute transporter subunit $\beta$ )

http://www.guidetopharmacology.org/GRAC/ObjectDisplayForward?objectld=1916

\section{References}

1. Alexander SPH, Kelly E, Mathie A, Peters JA, Veale EL, Armstrong JF, Faccenda E, Harding SD, Pawson AJ and Sharman JL et al.. (2019) THE CONCISE GUIDE TO PHARMACOLOGY 2019/20: Transporters. Br. J. Pharmacol. 176 Suppl 1: S397-S493 [PMID:31710713]

2. Ballatori N, Christian WV, Lee JY, Dawson PA, Soroka CJ, Boyer JL, Madejczyk MS and Li N. (2005) OSTalpha-OSTbeta: a major basolateral bile acid and steroid transporter in human intestinal, renal, and biliary epithelia. Hepatology 42: 1270-9 [PMID:16317684] 
3. Christian WV, Li N, Hinkle PM and Ballatori N. (2012) $\beta$-Subunit of the Osta-Ost $\beta$ organic solute transporter is required not only for heterodimerization and trafficking but also for function. J. Biol. Chem. 287: 21233-43 [PMID:22535958]

4. Dawson PA, Hubbert M, Haywood J, Craddock AL, Zerangue N, Christian WV and Ballatori N. (2005) The heteromeric organic solute transporter alpha-beta, Ostalpha-Ostbeta, is an ileal basolateral bile acid transporter. J. Biol. Chem. 280: 6960-8 [PMID:15563450]

5. Fang F, Christian WV, Gorman SG, Cui M, Huang J, Tieu K and Ballatori N. (2010) Neurosteroid transport by the organic solute transporter OSTa-OST $\beta$. J. Neurochem. 115: 220-33 [PMID:20649839]

6. Gao E, Cheema H, Waheed N, Mushtaq I, Erden N, Nelson-Williams C, Jain D, Soroka CJ, Boyer JL and Khalil Y et al.. (2020) Organic Solute Transporter Alpha Deficiency: A Disorder With Cholestasis, Liver Fibrosis, and Congenital Diarrhea. Hepatology 71: 1879-1882 [PMID:31863603]

7. Li N, Cui Z, Fang F, Lee JY and Ballatori N. (2007) Heterodimerization, trafficking and membrane topology of the two proteins, Ost alpha and Ost beta, that constitute the organic solute and steroid transporter. Biochem. J. 407: 363-72 [PMID:17650074]

8. Sultan M, Rao A, Elpeleg O, Vaz FM, Abu-Libdeh B, Karpen SJ and Dawson PA. (2018) Organic solute transporter- $\beta$ (SLC51B) deficiency in two brothers with congenital diarrhea and features of cholestasis. Hepatology 68: 590-598 [PMID:28898457]

9. van de Wiel SMW, de Waart DR, Oude Elferink RPJ and van de Graaf SFJ. (2018) Intestinal Farnesoid X Receptor Activation by Pharmacologic Inhibition of the Organic Solute Transporter $\alpha-\beta$. Cell Mol Gastroenterol Hepatol 5: 223-237 [PMID:29675448] 